\title{
Brazilian mass culture through three visionary thinkers
}

\section{RESUMO}

Este ensaio trata do tema da cultura de massa e as suas propriedades no mundo contemporâneo através das perspectivas de três pensadores importantes: Noam Chomsky, Umberto Eco e Marshall McLuhan. A análise do Chomsky sobre o impacto da mass media na realidade política é discutida e são fornecidos contra-exemplos da cultura brasileira. Os insights de Eco em relação às propriedades de cultura em massa são abordados e ilustrados. O par frioquente de McLuhan é considerado no contexto de cultura de massa e, finalmente, as três visões são aplicadas à síntese moderna de todas a mídias: a Internet.

\section{PALAVRAS-CHAVE}

- Brasil

- Internet

- cultura de massa

\section{ABSTRACT}

This squib deals with the theme of mass culture and its properties in the contemporary world as conceived in the perspectives of three visionary thinkers: Noam Chomsky, Umberto Eco and Marshall McLuhan. Chomsky's analysis of the impact of mass media on political reality is discussed and counterexamples from Brazilian culture are provided. Eco's insights regarding the properties of mass culture are addressed and illustrated. McLuhan's cold-hot pair is considered in the context of mass culture and finally, all views are applied to the modern-day synthesis of all media: the internet.

\section{KEY WORDS}

- Brazil

- internet

- mass culture

\section{Jorge Campos FALE/PUCRS}

ef me introduce you to three important thinkers on the complex theme of mass culture and its properties in the contemporary world.

The first one, Noam Chomsky, professor of linguistics at MIT and perhaps the most famous dissident in terms of American politics, has written many important books on mass culture and mass media, analyzing their impact on the political reality. In this context, Chomsky has talked about what he calls the "Orwell problem". According to him, it is very impressive the contrast between the amount of information about a particular event that reaches people and their ignorance about that same event. How can this be explained, asks Chomsky? His answer is that this apparent paradox is due to the existence of mass media and its way of shaping people's minds. He calls this effect, more conceptually, "manufactured consensus". What does this mean? In the Chomskyan sense, the political power and mass media work together most of the time. Mass media represents the means through which people must think. Reality is eluded such that people reach the information and the way of understanding it at the same time. In this perspective, the factual information is objective and nobody can say that it is hidden. In another way, the subjective interpretation is truly imposed according to the interests of the political power. The mass media defenders generally say that at no other time have people been so informed; the mass media critics, like Chomsky, say that at no other time have people been so deceived. As expected of a dissident like Chomsky, the war in Iraq, for example, clearly illustrates this amount of information and at the same time the total ignorance.

Let me consider, without any ideological interest, the similar situation in Brazilian politics now. Initially, we have the impression that Chomsky's conception is problematic since there is a discrepancy between the large quantity of criticism against Lula and his fantastic potential to win the next election. Parallel to Bush's case, we have, regarding Lula, two apparent counterexamples to Chomsky's idea. First of all, mass media are attacking the political power; secondly, these attacks apparently do not work. What I would suggest to save Chomksy' arguments is that we need to introduce a small, but essential, difference between the content and the form of mass media effects. Indeed, the act of choosing a candidate and voting is not completely rational. This is to say that content is not the only factor in determining the decision. Unfortunately, we have an expressive percentage of votes mechanically decided, simply because the intense presence of this or that candidate generates a preference for him. Intel- 
lectuals tend to underestimate this kind of phenomenon because it is a threat to rationality. The name 'Lula' in the current context is incomparably popular, even though the man is attacked all the time. It is a clear example of the prevalence of form over content. So, we certainly agree with Chomsky, but it is important to keep in mind the two kinds of mass media effects.

Umberto Eco, perhaps the most famous Italian writer and thinker, has brought significant contributions to our understanding of mass media. Probably the most insightful of Eco's conceptions is that we need to decipher the true nature of mass culture before attacking it. For him, intellectuals, especially philosophers and sociologists, adore putting all the responsibility of conflicting facts, misunderstandings, potential for war, etc., on mass media collaboration and complicity. Eco thinks that this is absolutely wrong. Mass media is, in principle, a wonderful invention of modern civilization. It is not in itself guilty of anything. The problem is the use of it and maybe the fact that we do not adequately understand it. Eco offers us a useful and almost didactic list of mass culture properties. For example, in mass culture, pure information prevails over argumentation, consistent or not; emotional content prevails over rational analysis; sensationalism is preferred over discrete observations; unpredictable over trivial events; banalities on celebreties over serious political comments. According to Umberto Eco, these kinds of features constitute the nature of mass culture. This means that watching $t v$, for example, we are submitted to this context and its distortions, regardless of our critical background. Philosopher, scientist, ignorant person or whoever, all of us suffer the same effects when we are inside the mass media environment. Under this point of view, we need to put mass culture in the right place of our lives. That is, keep up with mass information but do not live exclusively from it.

Returning to Brazilian mass culture, one important consideration is that we have an impressive complex of mass media institutions in terms of tv networks, radio, newspapers, magazines, etc. This richness contrasts with our poverty, educational background and serious social inequalities. Because of this, our people are oversensitive to the mass media influence. The consequence, maybe the most crucial, is that our politics, for example, is completely determined by its representation in the context of mass media. Politicians strongly dispute television, radio and newspaper space because they know that the power of mass media is unbeatable. And again, the content is not the only force. Being in the media, regardless of motive, is the law. The case of celebrities is very illustrative. Once someone has been baptized a celebrity, all he or she needs is to keep in touch with a news-worthy fact. The power of mass media is so strong that a lot of celebrities have a life even after death, like Princess Diana, John F. Kennedy or Elvis Presley, etc. In more technical terms, mass culture produces a kind of possible world that works as if it were a real world.

Finally, let us refer to Marshall McLuhan and his original and very interesting ideas. This Canadian thinker, unfortunately already dead, was one of the most visionary intellectuals that dedicated himself to investigating mass culture phenomena. Among his inumerable ideas, two of them are spectacular insights about our contemporary reality. The first one is the comprehension that each sort of media is in fact some extension of man himself. For example, the wheel is an extension of our foot, the radio an extension of our ear, the electrical networks an extension of our nervous system, etc. This radically means that man and media are a whole in a certain sense, an inseparable unit. When I have a problem with my tires, it is as if I have a problem with my foot because in modern societies, I need the wheel like I need my foot given the fact that I have a large professional space to get around in. If I do not have a tv, or a radio, or even newspapers, I lose vital information about weather beyond my sight because my real life depends on a complex of facts. My virtual neighborhood can be in several cities or countries. Today, it is enough to think about the possibility of being without internet for a month, or weeks to clearly understand our dramatic dependence on mass media.

The other important concept in McLuhan's framework is the cold-hot pair. He says that if you compare two formulas like $1+1=2$ and $1+1 \ldots$ and if you consider someone's way of participating in the process of mathematic knowledge, you read the first one and you fill in the second. Your participation is different in each case. Extending to mass media vehicles, you can say, based on the same reasoning, that you just listen to radio and you watch $t v$ and fill it in. Why is that? Because tv, according to McLuhan, is a cold medium in which you can participate more intensively than you can with the radio. Another easy illustration is dark sunglasses in opposition to clear glasses. If you meet someone in a waiting room with dark sunglasses, your attention is naturally drawn to this person unconsciously interpreting his or her eyes. On the contrary, there is no similar attraction or interest to interpret the person with clear glasses because his or her eyes say everything.

As in the beginning, we are finalizing with some considerations on Brazilian mass culture. We are a country with a large part of our population living in medieval situation before printing. The book did not have its moment in our history and we are already in the mass media era. A large portion of Brazilian people do not read even one book. In our schools now, the book in its nature is a hot medium if compared with illustrated magazines whose cold form in terms of images and short texts about vari- 
ous subjects, calls our attention to complete fragments and fill in gaps. In this context, it is very difficult for us to stimulate young people to read extensive books when they have, in magazines and newspapers, a much more attractive and interactive reading experience. The case of internet and the web in general is absolutely crucial. Certainly, neither Chomsky nor Eco or McLuhan had the opportunity to evaluate their ideas considering the potential effects of internet on people's lives. In fact, internet is a kind of synthesis of all the other media. It is highly interactive, it combines the book, the magazine, $t v$, radio, etc., becoming the revolution of globalization in terms of culture. The whole world is interconnected by the internet and depends on the web for everything. For a third world country like Brazil, this is a big and wonderful challenge. People are much more informed and living the contrast between their local situation and the reality of the rest of the world. Fortunately, the digital era is cold in the McLuhan sense, with a balance between the emotional and the rational, in Umberto Eco's perspective, and, we hope, completely different in the future from the Chomskyan Big Brother. mfamecos

\section{REFERÊNCIAS}

ECO, Umberto. Apocalyptics and Integrators. Random House Mondadori, 2004.

HERMAN, Edward S.; CHOMSKY, Noam.

Manufacturing Consent. Pantheon Books, 1988.

MCLUHAN, Marshal. Understanding Media: The Extensions of Man. Gingko Press,1967.

The Medium is the Massage (written with Quentin Fiore; produced by Jerome Agel) Random House; 2000. 